\title{
South African Airborne Operations
}

\author{
Brig Gen McGill Alexander •
}

\section{Introduction}

Airborne operations entail the delivery of ground troops and their equipment by air to their area of operations. They can also include the subsequent support of these troops and their equipment by air. Historically, and by definition, this would encompass delivery by fixed-wing powered aircraft, by glider, by parachute or by helicopter.

Almost any troops can be delivered by most of these means. However, the technical expertise and physical as well as psychological demands required by parachuting have resulted in specialist troops being selected and trained for this role. Some of the material advantages of using parachute troops, or paratroops, are: the enormous strategic reach provided by the long-distance transport aircraft used to convey them; the considerable payload which these aircraft are capable of carrying; the speed with which the parachute force can deploy; and the fact that no infrastructure such as airfields are required for their arrival. Perhaps most attractively to cash-strapped governments, the light equipment scales of parachute units' makes them economical to establish and maintain.

There are also less tangible advantages: the soldiers selected are invariably volunteers with a willingness or even desire to tackle challenges; their selection and training produces tough, confident and aggressive troops, psychologically geared to face superior odds and to function independently from other units; and their initiative and self-reliance combined with a high level of physical fitness makes them suitable for a number of different and demanding roles.

On the downside, paratroops require an exceptionally high standard of leadership and discipline to prevent them running amok, as happened with the French in Algeria and the Canadians in Somalia. They also need to be kept constructively busy to maintain a firm grip of control over them. Their limited fire-support and lack of armoured protection makes them vulnerable to heavy conventional forces and their tactical mobility on the ground is often restricted to movement on foot. Also, their lines of logistical re-supply and casualty evacuation are at best tenuous, whilst their ability to act independently and effectively is seldom for longer than two or three days.

Airborne operations are, by their very nature, particularly apt for the application of the strategy of the indirect approach. Furthermore, the very concept of vertical envelopment facilitates the acquisition of the element of surprise in military operations. This is especially so in Africa, where financial constraints make it generally impossible for rebel groupings and even national governments

\footnotetext{
- $\quad$ Paper delivered at the Conference on "South Africa at War in the Twentieth Century," South African Military Academy, Saldanha, 4-6 September 2000.
} 


\section{Alexander}

to deploy sophisticated and integrated radar and anti-aircraft systems.

South Africa carried out numerous airborne operations during the latter part of the last century. In doing so, a significant level of expertise was built up in this field. Political, organisational and personnel changes, however, resulting from the process of integration which produced the new South African National Defence Force (SANDF) have substantially altered this level.

The aim of this paper is therefore to consider the SANDF's potential to carry out airborne operations as it enters the new millenium. This is done by identifying the types of airborne operations executed by South Africa during the twentieth century and assessing their military value. The current ability of the SANDF to undertake airborne operations is then estimated.

Although operational delivery by fixed wing aircraft, parachute and helicopter are considered, the actions are limited to those of specialist parachute units, excluding special forces. Many helicopter and some air-landed operations have been carried out by non-parachute units, but these are seen as beyond the scope of this paper. Because their organisation, tactics, and equipment are specifically tailored for the aircraft (both fixed and rotary-wing) which they use, the parachute units are seen as the exponents of airborne operations in the strictest sense.

\section{Early history: conceptualising vertical envelopment}

Colonel Sir Pierre van Ryneveld, then Director of Air Services carried out the first military parachute descent in South Africa in 1927.' It was done at Swartkops Air Station to show the pilots of the South African Air Force how reliable their new emergency parachutes were. Five young pilots followed their chief by successfully parachuting as well. ${ }^{2}$

During the Second World War, South Africa fought on the side of the Allies. Yet the first South African to qualify as a paratrooper was Robey Leibbrandt, who was trained by the Germans in $1940{ }^{3}$ Leibbrandt was a Nazi sympathiser who later landed on the Namaqualand coast, commenced Fifth Columnist activities, was arrested and imprisoned, only to be released by the new National Party government in 1948. ${ }^{4}$ The South African Air Force briefly established a Parachute Company in 1943, though this was disbanded before the troops were able to jump. ${ }^{5}$ Prior to this the South African Army had carried out battalion-sized air landing assault exercises using commandeered civilian Junkers Ju52/3 transport aircraft as early as 1940. But no South African airborne operations were carried out during the Second World War. However, an airlanded occupation of Lourenzo Marques (now Maputo), in the event of the Portuguese siding with the Germans, was planned and

Pilot's Flying Log Book (DD461) of Gen Sir Pierre van Ryneveld, SAAF Museum, Pretoria.

Interview with the late Brig H.J. Bronkhorst, SAAF, (retd), on $8 \mathrm{Sep} 92$. He was one of the pilots who jumped.

Lt Col G.C. Visser, OB Traitors or Patriots? (Johannesburg, MacMillan, 1976), p.56; H. Strydom, For Volk and Fuhrer (Johannesburg, Jonathan Ball,1982), p. 76.

Paul Leverkuehn, German Military Intelligence (London, Weidenfeld and Nicolson,1954), pp 124 - 127; Robey Leibbrandt, Geen Genade (Bloemfontein, Robey Leibbrandt, 1966), pp. 54-59.

5 SANDF Documentation Service, Archival Group CGS (War), Box 351, File "Paratroop Training". 
rehearsed by the 6th South African Brigade. ${ }^{6}$ It says much for the South Africans that such an imaginative operation was even considered in 1940, when airborne operations were virtually unknown. More than 60 South African officers and a handful of other ranks did serve on secondment to British Airborne Forces, participating in airborne operations in Italy, the south of France, Yugoslavia, Greece and at Arnhem, as well as in the Far East. But the end of the war signalled the end of the airborne idea in South Africa for the time being.

By 1960 South Africa, with its racist apartheid policy, was increasingly experiencing the hostility of the rest of the world. The emerging African and Asian nations were particularly vociferous in their condemnation of South Africa. Internally, the country was faced with mounting opposition to the white government from the unenfranchised black majority. Unrest was brewing and the police were using hard-handed methods to quell any outbreaks. Black nationalist organisations and the Communist Party of South Africa had been banned.

Faced with external and internal threats, it was inevitable that an arms build-up and modernisation of the armed forces would take place in South Africa. As part of this tendency it was decided in 1960 to establish a parachute battalion. It is quite possible that this was motivated at least in part by the outbreaks of violence early in 1959 in the neighbouring Federation of Rhodesia and Nyasaland, where sabotaged bridges, road blocks and airfields littered with petrol drums, boulders and tree stumps had cut off, isolated outposts for up to two weeks. Lorried infantry and even airtransported troops had been unable to bypass these obstacles. Paratroops or helicopters were clearly the solution.

In September 1960 an extremely demanding two-week selection course was held in Pretoria to decide on 15 volunteers to be trained as the core of the new unit. Under command of Commandant (Lieutenant Colonel) Willem Petrus Louw, who had fought with the 6th South African Armoured Division in Italy during the Second World War, those selected were sent to England later that month for their parachute training. ${ }^{7}$

They were all trained as paratroopers by the Royal Air Force's No 1 Parachute Training School at Abingdon, after which the majority qualified as parachute instructors while others underwent parachute packing courses. On their return to South Africa, most were transferred to 2 Mobile Watch, an engineer unit under command of Commandant Louw, which had been earmarked for conversion to a parachute unit. ${ }^{8}$

\section{Operation SWIVEL: genesis of tactical air-mobility}

Even before the return of these paratroopers at the end of December 1960, both 1 and 2 Mobile Watches had been mobilized for active service. The simmering internal unrest had erupted in riots and

$6 \quad$ Brig F.W. Cooper, DSO, The Police Brigade (Cape Town, Constantia Publishers, 1972), pp 16-17.

7 Maj J.J. Malan, “Onder die Wit Valskermdak," Commando, March 1961, pp 10-13.

8 SANDF Documentation Service, Archival Group AG (9), File AG 213/5/43 (SM), Part 1, SAPF Strength : 2 Mobile Watch. 


\section{Alexander}

armed violence in the Pondoland area of the black tribal territory of Transkei on South Africa's east coast. The police were unable to contain the situation and the military had to be called in to restore order.

The freshly qualified paratroopers were rushed straight out to join their new unit in the rainsoaked mountains and forest-covered valleys of Pondoland. Here they participated in South Africa's first heliborne operations. Using Air Force Sikorsky S-55 and recently acquired Allouette II helicopters, the soldiers of the Mobile Watches were transported into inaccessible gorges and onto distant mountain ridges to search for elusive rebels. ${ }^{9}$

By February, order had been restored and the Mobile Watches were withdrawn.

In a sense, this action, though not a bloody one, presaged the start of the Armed Struggle in South Africa and the confrontation between the white SADF and proponents of black resistance. It was a portent of things to come and signalled the value of air mobility in countering guerrilla activity. It was a lesson the French had learned and were learning in Indo-China and Algeria and the British in Malaya and Borneo.

\section{Establishment of 1 Parachute Battalion}

On 1 April 1961, 2 Mobile Watch was formally converted into 1 Parachute Battalion at Bloemfontein, right in the middle of the country. This location reflected the thinking at the time that state security was threatened from within South Africa. The paratroopers were therefore strategically sited for rapid deployment anywhere in the country. The rest of the year was spent building parachute training apparatus, testing parachutes (the first jumps were carried out on 4 August 1961 from a C-47 Dakota of the South African Air Force) and recruiting volunteers for the new unit. ${ }^{10}$

Before the end of that year a start was made on the first South African parachute course. As there were only 12 parachutes of various types available at the time, the course was a lengthy one. But on 29 January 1962 the first 48 South African-trained paratroopers received their wings. ${ }^{11}$

From the small regular army in existence at the time it was not possible to bring the new battalion up to strength, so in April that year a start was made on the parachute training of volunteers from the ranks of conscripts. The battalion grew fast after this, having received its first batch of German- made American T-10 parachutes, the type decided on after the tests carried out the year before. Training was hard and of a high standard, and 1 Parachute Battalion soon built up a reputation as the elite unit of the South African Army.

\section{Operation BLOUWILDEBEES: first helicopter assault}

\footnotetext{
9 SANDF Documentation Service, Archival Group C Army, Box no 451 (OC's Diary Op SWIVEL). SANDF Documentation Service, Archival Group KG, File KG/GPO/3/2/24/1 (Monthly Progress Reports on 1 Para $\mathrm{Bn})$.

11 The Friend, 30 January 1962 and Commando, April 1962, p23 ("Valskermmanne kry hul vleuels").
} 
British SAS in insurgency wars in Malaya and Aden. This experience had stood them in good stead to participate in their own growing war and had convinced them of the value of both parachute and helicopter operations in such conflicts. It also enabled them to pass on valuable techniques to the inexperienced South Africans. ${ }^{19}$ Also in Angola and Mozambique the liberation movements had been extending their operations and again helicopters played a crucial role in Portuguese efforts to counter the guerrillas. Here too, the South Africans studied the operations carried out. ${ }^{20}$

\section{First operational parachute jumps: strategic reach and deterrence}

It was in Namibia, however, that the paratroopers were to see increasing action at this stage. That same year of 1967, the UN decided to take over the administration of the territory. South Africa was not going to allow this to happen. Fearing an airborne invasion of Namibia by UN forces, South Africa hurriedly deployed troops into the territory in December that year. A company of paratroopers from 1 Parachute Battalion was flown to the airport at the capital, Windhoek, in C-130 aircraft. $^{21}$

Nothing came of the UN invasion, but thereafter South African paratroopers and other troops were deployed almost constantly on a rotational basis along the northern border of Namibia. For the first four years there was little guerrilla activity for them to contend with, other than the occasional planting of land mines. Very rarely, there was a light skirmish between paratroopers and SWAPO guerrillas. $^{22}$

Most of the patrolling along the border was done by policemen, but when the guerrillas stepped up their activities and the police began to suffer increasing casualties, a call went out for the military to help. After a particularly effective ambush by SWAPO on a police patrol in the Caprivi Strip in April 1973, a company from 1 Parachute Battalion took over active patrolling from the police. It now became the permanent task of the military. ${ }^{23}$

It was in this setting that the paratroopers carried out their first operational jump. At the beginning of June 1974 the South Africans received intelligence reports that two large groups of SWAPO guerrillas, each about 100-strong, were moving through Angola towards the Caprivi Strip of Namibia. $^{24}$

1 Parachute Battalion was tasked to send two companies to stop this advance. The first company flew out of Bloemfontein in two C-130s at 19 HOO on 4 June 1974, having had only eight hours warning for the operation. After a two-hour flight, they carried out a night drop just north of

\footnotetext{
19 Interviews with Col Jan Breytenbach (retd) on 28 December 1990 and Brig Frank Bestbier on 27 February 1991.

$20 \quad$ Lesse en Foute, pp 28-30

21 SANDF Documentation Service, Archival Group HVS, File HVS/203/6/2 (Operasie DIKMELK).

22 SANDF Documentation Service, Archival Group HVS, File HVS/203/6/5 (Operasie CRACKER BOX).

23 SANDF Documentation Service, Archival Group GOC JCF, File JCF/201/4/10 (Op BARUTA/FOCUS); Prof F.J. du T. Spies, Operasie Savannah (Pretoria, SADF, 1989), p 21.

24 SANDF Documentation Service, Archival Group C Army, File Army HQ/G/Ops/3/3 (Op FOCUS). 


\section{Alexander}

the border, inside Angola, not far from the base of Bwabwata.

One man was injured in the jump into a clearing in the African forest. The remainder headed north and laid ambushes in the path of the approaching guerrillas. The dropping zone (DZ) had been manned by pathfinders from 1 Parachute Battalion who had moved to the spot by vehicle from the airfield at Mpacha, where they had been deployed since 30 May 1974.

The day after the night drop, the same pathfinders took off from Mpacha in a light Cessna aircraft and did a free fall jump at Kongola in the Caprivi. However, their timing was bad. The second company of paratroopers was already on the ground. At $10 \mathrm{H} 00$, they had arrived from Bloemfontein to drop onto the DZ, which the pathfinders were meant to have marked out. This jump, too, was successful. Three C-130s had been used for the second drop, delivering both men and supplies, including small vehicles, by parachute.

The guerrillas got wind of the drops and turned back. Assisted by teams of special forces from 1 Reconnaissance Commando, the paratroopers then spent the next month engaged in pursuit operations, during which one of the special forces officers became the first South African Army soldier to be killed in action since the Second World War. In various contacts with some of the small groups that the insurgents had split up into, the paratroopers killed several guerrillas, without suffering losses themselves.

The danger posed by this major infiltration had been warded off, but there had been no real airborne plan and the drops had not been executed tactically. Yet the paratroops had shown their potential to react at short notice and high speed over vast distances. The concept of strategic reach had been illustrated by deploying two companies and their supplies over a distance of $1,300 \mathrm{~km}$ within a day of having been warned. That this capability was seen as a deterrence by the guerrillas is apparent from their reluctance to subsequently field such large and concentrated groups of insurgents, and the relative quiet which prevailed in the Caprivi for the next year. After this operation a paratrooper company was permanently deployed on rotation in the Caprivi. Jumps were often conducted by this company at different locations as a show of force to the local population.

\section{Luiana: rapid reinforcement reaction}

At the time Angola was going through a major upheaval. The Portuguese Revolution of 1974 had resulted in a decision to withdraw from the colonies, threatening white South Africa with the removal of two of its most important buffers in the form of Angola and Mozambique. Independence for Angola was set for November 1975, and the South African government was most anxious that the Marxist Popular Movement for the Liberation of Angola (MPLA) should not take over the reins of power. The MPLA was very sympathetic towards SWAPO, and an MPLA government in Luanda would certainly afford SWAPO host facilities inside Angola.

In the state of political flux which prevailed in Angola during 1975, South Africa tried hard to woo the two rival, Western orientated liberation movements, the National Union for the Total Independence of Angola (UNITA) and the National Front for the Liberation of Angola (FNLA). Military training aid, advisers and weapons from South Africa formed part of this effort. 
One night in July 1975, a company of former Portuguese Army Bushman (San) trackers, abandoned to their fate in the chaos of Angola by the withdrawing Portuguese military and subsequently taken over by the South Africans, found themselves in trouble. Boxed into a swampy trap at the confluence between the Luiana and Kwando rivers in the south-eastern corner of Angola, they were besieged by a large SWAPO force.

The South African commander, assisted by a handful of South African and former Portuguese officers and NCOs, radioed desperately for help.

In the town of Rundu, some $350 \mathrm{~km}$ away on the Namibian border, a platoon of paratroopers was watching a film inside the military base. They were stationed there for a three-month tour: one of the constant operational commitments of 1 Parachute Battalion. They were due to be relieved the following day, and had already packed their gear. ${ }^{25}$

The platoon commander was hurriedly tasked to reinforce the besieged San company by means of a parachute drop. No helicopters were available, the distances were in any case prohibitive and time did not allow for an alternative. The position was critical. Twenty men drew parachutes and prepared their kit. They boarded the only aircraft available, a C-47 Dakota, and flew that same night to Immelman Airfield, close to the Kwando River inside the Caprivi Strip, but right alongside the Angolan border.

Here they waited, until just before dawn when they fitted parachutes, again emplaned, and the Dakota took off. At first light the aircraft was running in over the long-deserted dirt airstrip just south of the little settlement of Luiana. The paratroops jumped onto this airfield.

Their tiny force hurriedly grouped on the airfield and advanced on the fork in the river to engage the besieging guerrillas. It wasn't necessary. As soon as the SWAPO guerrillas had seen the parachutes blossom behind them, they had fled without bothering to count the canopies. The little airborne force linked up with the Bushmen, bringing much needed medical supplies and ammunition, though they were immediately subjected to a mortar attack by SWAPO.

After two days of follow-up operations in the marshy terrain and tall grass, during which several guerrillas were shot, a convoy of vehicles arrived to withdraw the paratroopers and the Bushmen. It had been a small airborne operation, but a singularly successful one. Again, the speed at which a parachute force could be deployed over a considerable distance had been illustrated. It had been a classical reinforcement action and the minuscule force involved had had an effect out of all proportion to its size. Surprise, speed, distance, audacity and aggression, all characteristics of airborne operations, had typified this one.

\section{'Fire force': acme of tactical air mobility}

The problems in Angola prior to independence soon erupted in a civil war between the three main liberation movements. The Portuguese, anxious to be rid of this boiling burden, hurriedly

25 Interview with Cmdt Johan Blaauw on 20 July 1990.

Scientia Militaria 31(1) 


\section{Alexander}

withdrew in November 1975, leaving the capital city, Luanda, to the MPLA, which established the de jure government. However, de facto, each movement controlled its traditional area of operations, and neither the FNLA nor UNITA were prepared to accept the new government; so the war merely escalated after independence.

South African involvement with the FNLA and UNITA was surreptitious, and even more surreptitious was US support of their efforts. The war had become part of the Cold War power play, as Soviet surrogate Cuban forces were sent to bolster the MPLA. South Africa was very quickly sucked into combat in Angola, against both MPLA and Cuban forces. Soon South African troops, wearing olive-green "foreign" uniforms, were deployed in increasing numbers in what came to be known as Operation SAVANNAH.

The paratroopers of 1 Parachute Battalion were amongst the first to be deployed, and fought with distinction throughout the war as conventional infantry. Unfortunately they were pennypackaged as platoons and companies attached to other units. Golden opportunities to employ airborne troops were lost because commanders never understood how to use them or were not prepared to risk using them and because the paratroopers were not prepared for an airborne role.

Towards the end of 1975 the South Africans had virtually exhausted their available full-time forces, and a decision was made to call up units of the Citizen Force (CF). In 1972, a CF parachute unit had been established to accommodate the many hundreds of conscripts who had been trained as paratroopers during their initial one year of full-time National Service. This unit, 2 Parachute Battalion, was tasked to call up one company for three months to participate in Operation SAVANNAH. ${ }^{26}$

This company was only deployed inside Angola for a few weeks early in 1976 before a political decision was made to withdraw all South African elements from that country. The paratrooper company thereafter deployed to the South African Air Force (SAAF) base at Ondangwa in northern Namibia. By then SWAPO guerrillas had capitalized on the chaos in Angola, and had stepped up their campaign of infiltration and insurgency inside the territory. South African forces in Namibia were involved in skirmishes with SWAPO groups on an almost daily basis, and the paratroopers were employed as a "reaction force", flying out in Puma helicopters to the scene of any contact with guerrillas, to take over the action from ground forces.

This concept soon became a permanent feature of the war in Namibia. Parachute companies from both 1 and 2 Parachute Battalions would rotate to always provide one company at Ondangwa in this role. The lessons identified from Operation BLOUWILDEBEES were fruitfully applied in these tactical air-mobile actions.

By 1977 a second CF unit, 3 Parachute Battalion, had been established to absorb the increasing numbers of paratroopers being produced by the National Service system, soon extended to two years' initial service. This battalion immediately also commenced sending companies to Ondangwa.

Back in Rhodesia, where the insurgent war had seen a marked increase since early 1973, a similar requirement had developed. Known by the Rhodesians as "Fire Force", it was based on a far 
more pre-active technique than the "Reaction Force" of the South Africans. The Rhodesians would send out observation posts (OPs) into areas known to be used as infiltration routes by guerrillas, or would even infiltrate guerrilla groups by means of "pseudo" special forces. Their Fire Forces (they formed several) would be mobile, and would be moved to a dirt airstrip anywhere near where OPs or pseudo groups would be operating. ${ }^{27}$

As soon as a guerrilla group had been pinpointed, the Fire Force would be called in to destroy it. Troops would be helicoptered in, and a helicopter "gunship" (an Allouette III with a 20mm cannon mounted in the side-door) would provide fire support. Another Allouette III would serve as an airborne command post, with the company commander directing the operation from the air while orbiting the battlefield.

Restricted to a limited number of the small Allouette helicopters, the Rhodesians found it difficult to transport sufficient numbers of troops to the contact area. They therefore resorted to using paratroopers, flying half their force out in helicopters and the other half in a C-47 Dakota. Their level of activity became so high that at times some paratroopers were carrying out up to three combat jumps in one day on these small-scale operations. Their success rate reached phenomenal heights. ${ }^{28}$

Impressed by their achievements, the South Africans attached some of their paratrooper officers to Rhodesian Fire Forces to learn the technique. Fired with enthusiasm, they tried to implement the offensive Rhodesian ideas in Namibia. They met with considerable resistance from the nonparatrooper military establishment, who favoured the positional, reactive approach for the employment of the paratroopers. ${ }^{29}$

Nevertheless, the paratroopers themselves understood the concept and after working in conjunction with special forces or the counter-guerrilla 32 Battalion (a unit of former FNLA guerrillas) were able to implement Fire Force with considerable success. This was particularly so using the fast Puma helicopters, which were able to transport 12, troops each. On occasion, when SWAPO guerrillas succeeded in penetrating far south, into the "white farmlands" of Namibia, the Fire Force would be moved from Ondangwa to Tsumeb, Otavi, Otjiwarongo or one of the isolated and lonely farms in the area. When this more mobile approach was followed, remarkable success would be achieved in hunting down the guerrillas.

By 1979 the situation in Rhodesia had reached crisis proportions. The Rhodesians were losing the war despite their tactical successes. Political negotiations were pointing to an election in which the liberation movements would participate. However, during the negotiating, the war intensified. The South African government, concerned that the conflict would spill across their northern border, agreed to provide military assistance to the Rhodesians.

Amongst other aid, two Fire Forces were deployed in the south of Rhodesia as part of Operation BOWLER, manned by South African paratroopers who were dressed in Rhodesian

\footnotetext{
27 Barbara Cole, The Elite (Amanzimtoti, Three Knights, 1984), p85.

28 Assegai, April 1977 ("1 RLI Notes"), pp11-12.

29 Interview with Brig A.L. van Graan on 26 February 1991. 


\section{Alexander}

camouflage fatigues. With their own Pumas, Allouettes and Dakotas at their disposal, and employed by the Rhodesians in a highly mobile, pre-active manner, the South Africans achieved incredible success, killing large numbers of guerrillas. With their own pathfinders joining the Rhodesians as OPs, the South African paratroopers experienced one of their most active periods. ${ }^{30}$ Companies from 1, 2 and 3 Parachute Battalions rotated for tours ranging from six weeks to two months, ensuring that one company each always manned the two Fire Forces. This operation was maintained for six months, between September 1979 and February 1980 when the election finally took place and Rhodesia became Zimbabwe.

Back in Namibia, the Fire Force role continued to be the staple activity of the paratroopers on a more or less constant basis. The South African military authorities insisted on calling it a "Reaction Force", but to the paratroopers it was "Fire Force". Almost always, there was a company of paratroopers on standby on the edge of the tarmac airfield at Ondangwa. Over the years, the paratroopers, so as to allow fairly sophisticated airborne operations to be conducted on a small scale, refined the technique for Fire Force.

One of these refinements was known as "Lunar Operations". Conducted only when the moon was bright enough to make them possible, Lunar Operations were executed at night as a form of curfew enforcement. A Dakota aircraft carrying paratroopers would take off and cruise around high above Ovamboland. Lower down, an Allouette III helicopter, carrying the paratrooper company commander or his second-in-command would fly a pattern across the various roads in areas where guerrillas were known to be active. It would be accompanied by an Allouette gunship. ${ }^{31}$

As soon as a vehicle was seen to be moving along one of the roads it would be identified as a curfew-breaker and the Dakota would be called down to a drop height of 800 feet. The vehicle would be brought to a stop by the gunship firing in front of it with $20 \mathrm{~mm}$ high explosive shells, while the commander would drop a white phosphorous grenade to mark the DZ, and a stick of five or ten paratroopers would be dropped. On landing, they would immediately close on the vehicle and apprehend the occupants. Sometimes this would result in a firefight, but more often than not the curfew breakers would surrender without resistance. Using night-vision equipment, such an operation would only take a few minutes once the vehicle had been spotted.

Although they achieved many successes with this type of operation, the paratroopers had to find a more active, aggressive manner to combat the guerrillas by day. They therefore developed "Rubber Duck" and "Bakkie Operations". The former entailed sending out a relatively vulnerable vehicle patrol, small, but using mine and small-arms resistant armoured vehicles. This patrol would move into an area known to be "contaminated" by guerrillas, in the hopes of running into an ambush. Shadowed by a Dakota (sometimes two) loaded with paratroopers, the convoy's position would constantly be monitored. When the ambush was sprung, the Paradak would suddenly appear and drop its paratroopers behind the guerrillas. Controlled by the company commander in an Allouette and supported by a gunship, a properly run Rubber Duck operation would trap and annihilate the guerrillas. Clearly, such operations could not be conducted in an ad hoc manner and required good 
intelligence of expected guerrilla activities.

Bakkie is the term applied in South Africa to a light pickup truck. Bakkie Operations were a daytime variation of Lunar Operations and entailed the identifying, stopping and searching of any suspicious looking bakkies which might be moving along one of the hundreds of sandy tracks between the sparse forests of Ovamboland. The guerrillas often made use of such vehicles, owned by locals, to transport weapons, food and other supplies. Vehicles would be cut off and captured by paratroopers dropped from a Dakota and controlled from a light reconnaissance aircraft. In effect, such operations boiled down to hasty, airborne vehicle check points, and were often done in a very haphazard way. Nevertheless, they did on occasion yield results, with guerrillas and weapons being captured.

In all these operations, troops were delivered by parachute rather than by Puma helicopter because of the Dakota's superior ability to remain aloft for long periods, and its cheaper running costs. The flat terrain of Ovamboland made night parachuting very feasible, though the large numbers of trees was an ever-present hazard which paratroopers had to overcome.

The Rhodesians had never refined Fire Force to the level that the South Africans achieved. Rhodesian Fire Forces shut down at night, but towards the end of the war in Namibia the South African version was at its most active after sunset. Tactical air mobility had reached its zenith in these counter-guerrilla operations.

Another variation of Fire Force operations was search and rescue, or "S and R". The SAAF would frequently carry out opportunity strikes against SWAPO forces, bases and convoys in Southern Angola. When this happened, the Fire Force at Ondangwa would be placed on standby for search and rescue duties, should one of the aircraft be shot down. On several occasions this happened, and the paratroopers were helicoptered in to find the pilot who had baled out, and to blow up anything that may be left of the aircraft to prevent it falling into enemy hands. Sometimes this would result in running gun battles on the ground as paratroopers and guerrillas fought for possession of the airmen or the aircraft wreck. ${ }^{32}$

\section{Strategic independent pre-emptive raids}

By 1978 SWAPO had built up its forces in Angola to the extent that it was launching increasingly effective infiltrations into Namibia. Secure in the knowledge that the MPLA government, backed by the Cuban military, was giving them full support, the SWAPO guerrillas were in fact operating into Namibia with impunity.

The South African military chiefs, charged by their government with preventing these invasions, realised that drastic action would need to be taken if the initiative was to be regained. The paratroopers had been operating across the border inside Angola with 32 Battalion, carrying out small-scale harassing activities and shallow reconnaissance missions. Generally, however, the South

32

A. van Wyk, Honoris Crux - Ons Dapperes/Our Brave (Cape Town, Saayman and Weber, 1982), pp 101-103. 


\section{Alexander}

African forces were only operating on the Namibian side of the border, on a purely reactive basis.

SWAPO had established its forward operational military headquarters, its major recruit training base, its main logistics centre and a rest and recuperation resort, all at the former mining settlement of Cassinga. ${ }^{33}$ Located some $260 \mathrm{~km}$ north of the Angolan/Namibian border, this base was identified by the South African military intelligence as housing in excess of 1500 SWAPO guerrillas, a number of Cuban instructors and an unknown but considerable number of civilians. These were mostly refugees from Namibia who supported SWAPO. The South Africans, however, alleged that they were victims of abduction, forcibly brought to Angola to be trained by SWAPO.

The headquarters at Cassinga was allegedly responsible for planning and co-ordinating all guerrilla operations into what they and the rest of the world called Namibia. These operations were conducted from several forward operational bases, none further than $50 \mathrm{~km}$ north of the border. A plan was devised by the South Africans, largely at the instigation of artilleryman and paratrooper Lieutenant General Constand Viljoen, Chief of the South African Army, whereby Cassinga would be attacked by an airborne force, while the forward operational bases would be attacked by a mechanised force. The prime minister, B.J. Vorster, was persuaded to authorise the raid.

Earlier that year a decision had already been made to establish a parachute brigade, also apparently at the instigation of Viljoen. He was the one person who had recognised the strategic potential of a balanced airborne force when, as the Army's Director of Operations, he had directed the first operational parachute drops in the Caprivi in 1974. As an artilleryman, Viljoen saw the airborne concept in far broader terms than merely an infantry capability on the tactical level, such as the Fire Force. He had the vision to identify a need for organic fire-support, an engineering ability and proper logistic sustainment for independent airborne operations of a strategic nature. Hence the formation, early in April 1978, of a parachute brigade headquarters in Bloemfontein to command the one full-time and two part-time parachute battalions. It was envisaged that an airborne artillery regiment, engineer squadron, signal squadron and maintenance element would also soon be included in the new brigade's order of battle. This new brigade, still in the process of being organised and yet to be named, was tasked with carrying out the assault on Cassinga.

It was to be a battalion-sized operation, and for various reasons not one of the three units could provide a full battalion at that stage. The attack would therefore be done by a composite battalion, formed from all three. ${ }^{34}$

The CF paratroopers were called up to Bloemfontein, where the battalion was formed and trained under heavy security for a week. On the evening of 3 May 1978 it was flown to the air base at Grootfontein in Namibia, $1350 \mathrm{~km}$ away. There the paratroopers spent the night in an empty aircraft hangar.

More than 600 paratroopers were poised for the attack to take place the next day. For the actual parachute assault, 380 paratroopers would be dropped. These were divided into four under-

SANDF Documentation Service, Archival Group CS Ops, File CS Ops/310/4/Reindeer.

Col Jan Breytenbach, "Gefechtssprung aufCassinga”, Barett Internationales Militärmagazin, 3/93, May/June, p 22. 
strength companies, a mortar platoon and an anti-tank platoon, with the battalion headquarters. A full-strength company of 128 would be used as an immediate airborne reserve, while half a company provided a protection element for the helicopter administrative area (HAA) to be established inside Angola, and half a company stood by as an additional reserve to be parachuted or helicoptered in if necessary. ${ }^{35}$

Nine transport aircraft were to be used. Four C-130B Hercules and two C-160Z Transall aircraft would drop the paratroopers. Two more C-160s would carry the airborne reserve, while another would stand by, loaded with additional ammunition, palletised and rigged for airdrop. ${ }^{36}$

Pre-dawn on Thursday 4 May 1978, four Canberra bombers and four Buccaneer strike aircraft took off from Pretoria to fly directly to Cassinga. At $06 \mathrm{HOO}$ the nine transport aircraft took off from Grootfontein. The C-160 carrying the reserve ammunition landed at Ondangwa, where it stood by throughout the operation. The two carrying the airborne reserve (rigged and ready to jump) went into a holding circuit above the border. The six aircraft carrying the force to be dropped continued to above the upper reaches of the Kavango River, where they also went into a holding circuit.

In the meantime, 12 Puma and five Super Frelon helicopters, with half a company of paratroopers and drums of helicopter fuel, flew out to an isolated clearing in the bush, $22 \mathrm{~km}$ east of Cassinga, and established an HAA. At 07H30, two Mirage III CZ fighters took off from Ondangwa.

The attack on Cassinga commenced at $08 \mathrm{HO} 2$, while those in the base were on morning muster parade. First the four Canberras swept in to drop anti-personnel bombs, followed immediately by the four Buccaneers doing precision bombing of pre-selected targets. The two Mirages then strafed the recruits' camp and the transport park.

Like the fast attack aircraft, the slow transports approached from the north, but coming in at 200 feet above ground level. Two minutes out from the DZs, they pitched up to the drop height of 800 feet and split apart for their different final approaches. One aircraft dropped a two-platoon company east of Cassinga to form a stop line. The actual assault force (two companies, each of only two platoons), the mortar platoon, battalion headquarters and brigade headquarters were dropped by three aircraft to the west of the objective.

Seconds later the remaining two aircraft crossed from east to west. They dropped two rifle platoons to the north of Cassinga, with one rifle platoon and the anti-tank platoon to the south. The plan was designed to effectively seal off the objective before launching the ground assault from the west.

However, the drop was less than successful. Subjected to small arms fire during the run-in and with the target obscured by smoke and dust from the air strike, most of the aircraft dropped their paratroopers late.

\footnotetext{
35 A detailed Orbat has been reconstructed by the writer, based on numerous interviews, official documents and aircraft load manifests. This was used as a basis for the numbers quoted.

36 SANDF Documentation Service, Archival Group LMH, File LMH/309/4/REINDEER. 


\section{Alexander}

For those who were to form stop lines this meant that many guerrillas and civilians escaped before they could close the "box". But for the assault companies it had almost disastrous consequences. About one and a half companies landed on the wrong side of the Culonga River, a relatively narrow but deep and swift flowing stream. ${ }^{37}$

Several paratroopers landed in the river, losing much of their equipment and almost drowning. A third of all the mortar tubes and bombs were lost in the river, as well as half the medical supplies and much other equipment.

A strong wind was blowing and most of one company was scattered across a rocky hillock. One of the northern stop line platoons was inadvertently dropped right on top of a tented recruit camp. They were fighting even before they hit the ground.

All the drops experienced some small arms fire during the parachute descents, which took place over bush and open forest, with many paratroopers being hooked up in tall trees. Two of the companies were involved in firefights with fleeing guerrillas in the bush as soon as they had landed.

About five men were injured on landing, one suffering a nasty leg fracture and another severe concussion. One man, never accounted for, was believed to have been drowned in the river. He could also have been shot in the air before landing in the river, his heavy equipment dragging him under the water.

Above the chaotic battlefield, a Cessna aircraft was orbiting to help with navigation. It directed some of the paratroopers to a ford across the river, but had to withdraw when it drew fire from an anti-aircraft gun.

It took the battalion commander over an hour to restore order, get his assault force across the river and form up for the attack. Not realising just how far south they were, they commenced their attack along the wrong axis, realised their mistake, changed the axis and ultimately attacked from south to north. However, not before two companies of paratroopers had accidentally exchanged fire, fortunately without casualties.

Initially, resistance was light, but it soon stiffened. In the north, a platoon had been clearing some isolated buildings when a Forward Air Controller with the paratroopers mistakenly authorised an air strike on them. A fifth Buccaneer, armed with rockets, had been doing a combat air patrol above Cassinga. It now attacked the buildings, and two paratroopers were badly wounded by shrapnel before the strike was called off.

Many guerrillas and civilians had fled, but eventually the stop lines managed to get into position after the inaccurate drop, and Cassinga was almost sealed off. To the south, the anti-tank platoon, armed with RPG-7 rocket launchers, had moved down the road leading to the town of Techumatete, laid tank mines and occupied ambush positions. Just $16 \mathrm{~km}$ away, Techumatete housed a Cuban armoured battalion, so a counter-attack from that direction was expected.

The SADF version of the battle, as summarised here, was gleaned from numerous interviews from survivors, with timings, quantities, casualties, etc corroborated from various official documents in the archival collection of the SANDF Documentation Service. 
The two assault companies had in the meantime fought their way to the centre of Cassinga, where they were held up by a twin barrelled ZU-23 and two ZPU-4 anti-aircraft guns employed in the ground role. The guns were deployed in the vicinity of the SWAPO headquarters. One company tried to by-pass them, but was pinned down by fire from the perimeter trenches.

All efforts to silence the guns proved futile. Every time the paratroopers killed the gun crews fresh crews who leapt out of the nearby trenches to man the lethal weapons replaced them. The paratroopers were deeply impressed by the bravery and determination of the SWAPO defenders.

The assault was held up for two hours, while the companies tried to attack the guns from different directions. Eventually, one of the company commanders, with a few men, worked his way towards the guns by clearing trenches with grenades, and finally silenced them with mortar support. Three paratroopers died in the battle around the guns and about nine were wounded, including the battalion commander. Several others were wounded during house-clearing actions.

With the guns silenced, the paratroopers were able to take their objective, as all further resistance evaporated. After reorganising their force and searching the base, they set fire to the buildings and began destroying weapons, ammunition and stores while gathering documents. The helicopters were then called in from the HAA to extract half of the battalion.

This had no sooner taken place than the Buccaneer reported that an armoured column was approaching from Techumatete. The anticipated counter-attack was about to commence. The Buccaneer engaged the Cuban armour, which then ran into the mines laid by the paratroopers. Several armoured personnel carriers (APCs) were knocked out by the anti-tank platoon before they withdrew to join the remainder of the battalion on the emergency helicopter landing zone (LZ). There the helicopters extracted the last paratroopers as the T-34 tanks and APCs arrived on the LZ. It was a hot extraction, conducted under fire, but by nightfall the battalion was back in Namibia. The mechanised attacks on the other bases had all gone according to plan.

It is estimated that close to 800 guerrillas and civilians died in the airborne attack, as well as about 100 Cubans and a number of MPLA soldiers. The SWAPO operational headquarters had been destroyed, their morale shattered and their international image badly dented. Three tanks, 17 APCs, seven trucks and three anti-aircraft guns were destroyed, according to SAAF reports.

The paratroopers lost three men killed in action, one missing believed killed, 12 wounded and five injured during the drop. Within three days all the Citizen Force paratroopers had been demobilised and were back at their civilian jobs. They had been in uniform less than two weeks. It was the largest airborne operation to be carried out by the South Africans, and was considered by them to have been singularly successful. Yet although the concept of the Cassinga operation was sound from a military airborne doctrinal view, many aspects of the operation had gone wrong. The paratroopers undertook a detailed and critical self-analysis to correct failings in any future airborne operations.

The attack on Cassinga was extremely controversial, as SWAPO claimed that the base had been only a refugee camp and that almost all of those killed had been innocent civilians, brutally 
slaughtered by the aggressive paratroopers. ${ }^{38}$ International media were invited to the site to view the scene of the massacre, and the South African action was denounced in world bodies such as the UN. ${ }^{39}$ The South African government remained adamant that Cassinga was a legitimate military target, housing key military elements and infrastructure. ${ }^{40}$ Evidence appears to indicate that both claims contain elements of truth.

The controversy aside, the airborne assault on Cassinga was a classic example of an independent, strategic operation. It was independent because no ground forces were involved. The new brigade had conducted the operation only with the Air Force. There was never a link-up with ground forces, and the composite battalion was throughout under command of the parachute brigade headquarters. The operation was strategic in terms of the objective that was attacked. SWAPO's activities in southern Angola were curtailed considerably for almost two years after the destruction of Cassinga. The ability of the SADF to strike so deeply into this area caused SWAPO to re-assess their concentration of base facilities. In future they would disperse their layout and shift some bases to Zambia. $^{41}$ This resulted in a decrease in guerrilla activities in Ovamboland and an increase in the Caprivi Strip.

Based on the lessons of Cassinga, the brigade, now named 44 Parachute Brigade, subsequently planned further independent actions under the altered circumstances. Though not strategic, they were important for building the concept of independent airborne operations. One of these, Operation SAFRAAN, was to have included a battalion-sized parachute drop onto an insurgent base in southwestern Zambia in March 1979. Three companies from 1 Parachute Battalion were poised in their aircraft, hooked up and seconds away from jumping, when the message came through: "Stop drop the Air Force has bombed the wrong target!" It later transpired that there had in any case been a security leak, and the actual base had been vacated the night before. ${ }^{42}$

A more successful operation later that year was STOOMPOT, when a company from 1 Parachute Battalion was dropped into the Njinji Forest in Zambia, where they spent several weeks hunting guerrillas. A number of insurgents were killed, bases were discovered (abandoned by the guerrillas as soon as they realised the paratroopers were hunting them) and weapons and documents were seized. One paratrooper was killed in a skirmish. ${ }^{43}$

In the meantime, the war in Rhodesia was drawing to a close as the Lancaster House talks resulted in a shaky negotiated settlement. With a Commonwealth monitored election planned for February 1980, the South African government was intensely concerned about the outcome and was engaged in top-level collusion with the Rhodesians. On the military front, the paratroopers from 44 Parachute Brigade had been deploying their very successful Fire Forces in the southern part of Rhodesia for six months. Now the brigade was to prepare a contingency plan for an independent,

The Natal Mercury, 9 May 1978 ("5 100 die in raid, claim Angolans")

Sunday Tribune, 7 May 1978 ("Oil threat as West joins UN censure")

The Star, 10 May 1978, ("SWAPO's guerrilla army on parade - Captured 'Moscow' films on show").

Willem Steenkamp, Borderstrike! (Durban, Butterworths, 1983), p 140.

Interview with Brig "Archie" Moore (retd) in 1994.

Operational Diary of D-Company, 1 Parachute Battalion for 1979. 
battalion-sized intervention known as Operation MELBA.

The Rhodesians, expecting the moderate Bishop Abel Muzorewa to win the elections, had planned to attack the various assembly points that had been established throughout Rhodesia. In these assembly points guerrillas from the liberation movements had been gathered in terms of pre-election agreements, under control of Commonwealth Monitoring Forces. Their would have enabled the Rhodesians to eliminate large numbers of guerrillas in one fell swoop, severely setting back any attempt by the liberation movements (who under this scenario would have lost the election) to continue the war.

In support of the Rhodesian plan, South Africa agreed to attack Assembly Point JULIET, some $50 \mathrm{~km}$ north of the South African border. 44 Parachute Brigade was tasked to carry out this attack, and drew up a plan for it to be executed by 1 Parachute Battalion. ${ }^{44}$ The battalion would drop two companies by parachute to seal off the assembly point, and bring in two more companies by helicopter to do the actual attack. It was rehearsed, on the South African side of the border, in the bush around the isolated airfield of Madimbo. But when the "wrong" candidate won the election, the forces standing by for the attack stood down and the South African Fire Forces were very hurriedly withdrawn from the new Zimbabwe.

By 1980 there had been serious personality clashes between senior officers of 1 Parachute Battalion on the one hand and 44 Parachute Brigade on the other. Army headquarters showed an inexplicable inability to resolve this issue. Eventually the brigade headquarters was deactivated, leaving the CF parachute units in limbo, until the brigade headquarters was reactivated in 1982, this time near Pretoria. 1 Parachute Battalion was now excluded from the brigade, though CF and National Service paratroopers continued to relieve one another for operational deployments.

The eighties saw a conspicuous growth in the South African parachute forces, with 1 Parachute Battalion expanding to an effective two-battalion strength and 44 Parachute Brigade gaining CF artillery, anti-aircraft, engineer and supporting units. A third CF battalion, 4 Parachute Battalion, was also established.

During the 1980s the Headquarters of 44 Parachute Brigade planned and conducted numerous airborne exercises, utilising the parachute battalion group concept. In the process a detailed doctrine on airborne operations was compiled, drawing heavily on past operational experience. Equipment and vehicles were designed, developed, tested and eventually brought into service with the units of the brigade. By 1990 the brigade had developed and exercised the capability to drop a battalion group of 600 paratroops with light artillery, logistic and command vehicles, as well as engineer and maintenance support and light anti-tank armoured cars, all in one wave of 18 aircraft $(12 \times \mathrm{C}-130 \mathrm{~s} / \mathrm{C}$ $160 \mathrm{~s}$ and $6 \times$ Dakota C-47s). ${ }^{45}$

The insurgency war for Namibia had, in the meantime, taken on a far more conventional nature

44

45

SANDF Documentation Service, Archival Group 44 Para Bde, Op Instructure for : Design for Battle, Op MELBA. Brigade Commander's Diary, 44 Parachute Brigade, 3-4 October 1989; Spectator Handout, "Exercise IRON EAGLE 90", 44 Parachute Brigade, 02 July 1990. 


\section{Alexander}

by the mid-eighties. Cuban forces in Angola had built up to significant levels and the MPLA forces had been equipped with large quantities of Soviet heavy weaponry. SWAPO and ANC forces, trained in conventional operations and also equipped by the Soviets, were deployed alongside the MPLA and the Cubans in the Angolan civil war.

Pitted against them were the forces of UNITA, surreptitiously equipped by the USA and heavily supported by South Africa. During 1985 and especially 1987/88, major clashes took place in southeastern Angola when the MPLA and Cubans attempted to take the UNITA headquarters at Jamba. The battles around the Lomba River and for Cuito Cuanavale saw the first employment of tanks by the South Africans in this war.

Over this period the paratroopers were employed mainly in smaller operations in the western and central parts of southern Angola, as well as in the ongoing Fire Force role inside Namibia. However, one light parachute artillery battery and the pathfinders were employed in the Cuito Cuanavale battles.

But the Cold war was coming to an end. The Soviet Union was faced with disintegration and world communism was collapsing. International events were overtaking the war in Angola, and continued Soviet support for the MPLA was withering. In addition, the South African ability to wage an extended conventional war was virtually exhausted. Economic realities and the effects of years of international sanctions were forcing the South Africans to reconsider their involvement in the resource-sapping conflict.

International diplomatic negotiations led to an agreement being reached for the implementation of UN Security Council Resolution 435 for the granting of independence to Namibia. In terms of this agreement, there would be a phased withdrawal of Cuban forces from Angola and of South African forces from Namibia. The run-up to the implementation was characterised by suspicion and posturing on both sides. Armed clashes continued to take place, initially in southern Angola, and later restricted to the continuing insurgency war between SWAPO and the SADF inside Namibia.

It was at this time, towards the middle of 1988 , that a composite and very powerful airborne unit was formed by the South Africans as part of 44 Parachute Brigade. Known as 14 Parachute Battalion Group, it comprised full-time and part-time parachute elements drawn from existing parachute units and serving for a few months at a time on a rotational basis. It included four infantry companies, a support company, artillery battery, anti-aircraft, engineer and armoured anti-tank elements. This unit was trained in amphibious operations, and using Walvis Bay in Namibia it rehearsed for a combined amphibious/parachute assault on the Angolan port of Namibe. ${ }^{46}$ Known as Operation HANDBAG, it aimed at destroying the harbour and railhead used to supply the main artery for the Cuban and Angolan forces ranged along the Namibian/Angolan border. This would have prevented an attack on Namibia by the poised Cuban 50th Division.

This operation was never carried out, and 14 Parachute Battalion Group was deployed instead in defence along the Angolan/Namibian border until the mutual withdrawal of forces began. The paratroopers then returned to South Africa, with the exception of one company, which continued to 
do duty as the resident Fire Force at Ondangwa, and remained there as the last combat element of the SADF to withdraw from Namibia. The planned raid on Namibe, however, was not the last independent strategic airborne contingency to be prepared by the parachute brigade. In October 1989, on the eve of the elections to be held in Namibia, the brigade was instructed to prepare for Operation SKYDART. This was to be a parachute assault by two battalions and an artillery battery on the city of Windhoek in the event of SWAPO carrying out a coup d'etat before the election had been held. Though it was not necessary to execute the operation, it was planned in great detail and rehearsed. That it was a viable undertaking illustrates the level of expertise that the brigade had achieved at this stage. It must be added though, that the envisaged force levels would have required virtually every transport aircraft in the SAAF and it would have been the largest airborne operation ever undertaken by the South Africans.

After this the altered political circumstances, changes in personnel and a rapidly diminishing defence budget spelt an end to the concept of independent strategic airborne operations. The vision disappeared in the flurry of change taking place in the decade of the nineties.

\section{Tactical airborne envelopment: secondary role to ground forces}

Far simpler to plan, execute and supply were the tactical airborne operations undertaken as an ancillary part of a larger ground operation. Such actions were normally carried out by one or two parachute companies attached to a mechanised or motorised force. They provided the ground commander with a useful airborne reach, enabling him to envelop an objective through a third dimension. Unfortunately for the paratroop commander, it removed most of his initiative and freedom of movement. It also placed him, more often than not, under command of someone who had no appreciation nor understanding of vertical envelopment and who probably also disliked "elite troops". This resulted in many bitterly disappointing deployments for paratroopers.

On other occasions they would be used to provide support when 32 Battalion carried out attacks. The white paratroopers were confined to the less risky tasks, while the black soldiers of 32 Battalion, regarded as more expendable, were given the job of carrying out the assault. The government did not have to make the deaths of black former Angolan guerrillas from 32 Battalion public. White national servicemen killed in action, on the other hand, were always an embarrassment.

Yet this "penny-packeting" of paratroopers, ironically, was at least in part due to the effect of the parachute assault on Cassinga. After Cassinga, towards the middle of 1979, it had become apparent that SWAPO was again building up its capability in Angola. Having learned an expensive lesson at Cassinga, they never again concentrated their whole infrastructure at one place. Elements were dispersed all over southern Angola, and bases covered a vast area.

As intelligence reports confirmed the existence of small concentrations of guerrillas close to the border, the South Africans launched quick opportunity assaults on them, using 32 Battalion. Generally no more than $50 \mathrm{~km}$ north of the border, these actions usually entailed the helicoptering in of soldiers. For some of these actions, such as Operation KURKTREKKER, in October 1979, a company of paratroopers would be parachuted in to form a stopline to prevent guerrillas escaping. 


\section{Alexander}

Such operations were sometimes successful, and as often produced no results at all. ${ }^{47}$

The first major operation of 1980, SCEPTIC, did not bode well for this type of airborne operation. Although 1 Parachute Battalion provided a total of six companies for the operation, only one of them was intended for an airborne role. This company was to accompany one of several mechanised battle groups about $100 \mathrm{~km}$ into Angola, and then be picked up by helicopters to be positioned as stop groups to prevent guerrillas escaping, while the battle group executed a deliberate surprise attack on the guerrilla base. However, someone forgot to bring along extra fuel for the helicopters, and the paratrooper company had to be used as conventional infantry. ${ }^{48}$

It was a glaring example of the dangers of placing airborne troops under command of nonairborne headquarters. Logisticians obsessed with supplying large numbers of armoured vehicles with fuel and technical support are apt to forget about the specialised requirements of a few helicopters.

As part of Operation BUTTERFLY in 1980, two companies of 1 Parachute Battalion were parachuted into Angola to form stop lines when 32 Battalion attacked a SWAPO base. Then in November 1981, 3 Parachute Battalion was parachuted in at night during Operation DAISY to cut off fleeing guerrillas when a major mechanised attack was carried out on a number of SWAPO bases. ${ }^{49}$

During the dying months of war in Rhodesia one such operation was carried out across the Limpopo River. In September 1979 a company from 1 Parachute Battalion was parachuted across the border from South Africa to join Rhodesian forces in a sweep through the dense bush to flush out guerrillas. A second parachute company crossed the border on foot and formed a stop line. This was called Operation STORING by the South Africans and Operation UNION by the Rhodesians. ${ }^{50}$

This concept of being merely the airborne arm of a ground force with no independent ability was always a source of frustration to the independent-minded paratroopers. It also wasted the greatest potential of a parachute force: that of strategic reach. Yet it subsequently became virtually the only doctrine for the employment of airborne troops by the SADF and eventually the SANDF.

After the withdrawal of South Africa from Namibia the SADF went through a series of rationalisation exercises to accommodate the massive budget cuts which were imposed on the defence establishment. In the first of these, at the end of 1980, both 14 Parachute Battalion Group and 4 Parachute Battalion were disbanded.

By 1991 further rationalisation was looming. It was decided to place 1 Parachute Battalion back under command of 44 Parachute Brigade and to move the brigade headquarters back to Bloemfontein.

This was the era of the so-called "Rapid Deployment Force" a divisional-sized monstrosity of hybrid composition. Armour, mechanised infantry, motorised infantry and parachute infantry were all thrown together under one headquarters for regular exercises at the Army Battle School, Lohathla,

47 Operational Diary of E-Company, 1 Parachute Battalion for 1979.

$48 \quad$ Willem Steenkamp, Borderstrike!, p191.

49 Interview with Cmdt Gerrie Steyn (retd) in 1989.

so Operational Diary of A-Company, 1 Parachute Battalion for 1979. 
and were to be available for immediate deployment. 44 Parachute Brigade had to provide a parachute battalion group, a pathfinder platoon and on occasion a brigade headquarters. 1 Parachute Battalion was now permanently reinforced and became known as 1 Parachute Battalion Group. Dominated by armour and mechanised infantry commanders, the Rapid Deployment Force soon relegated the paratroopers to a purely tactical role in support of the heavy mechanised units. The amphibious role of the paratroopers was also taken away and given to a conventional motorised infantry battalion. The expertise of the past years in this field was therefore quickly lost.

The brigade's independence was further undermined when the Officer Commanding Orange Free State Command managed to have the brigade placed under his direct command. The status of being an independent formation consequently disappeared, and from being directly under command of Chief of the Army the brigade fell into the position of having three bosses: the Officer Commanding Rapid Deployment Force for conventional operations and exercises, Director of Operations at Army HQ for routine and unscheduled deployments inside the country and the Officer Commanding OFS Command for everything else. ${ }^{51}$

Making the best of his unenviable situation, the brigade commander initiated exercises with the special forces, establishing a compact, high-mobility, high-firepower, air-transportable force mounted on Jakkals jeeps, to back up special forces in certain types of operations. Known as "Oscar Force", it participated in highly successful exercises with the special forces at Air Force Base Waterkloof and other locations. The Rapid Deployment Force was quick to latch onto the idea, and Oscar Force was used in some of their exercises at the Army Battle School to secure airfields. A concerted effort was also put into developing the brigade's pathfinder capability with a highly-trained platoon of full-time soldiers. Small, tactical innovations were possible, but the concept of a balanced, viable, lightlyequipped but potent force, capable of rapid deployment over both tactical and strategic distances by a variety of means, supported by a streamlined logistic system and built for flexibility, was rapidly being eroded. The brigade's independent strategic capability was for all practical purposes terminated due to the hijacking of the "rapid deployment" concept by elements that were patently not rapidly deployable.

In 1993 the government terminated compulsory conscription for white males. This impacted significantly on 44 Parachute Brigade, as it did on all other formations and units of the SA Army. For decades, trained national servicemen had been fed to the Citizen Force units of the army where they had completed further compulsory training camps or operational duty. Now, overnight, this annual inflow dried up. It meant that in future the $\mathrm{CF}$ paratroopers would consist solely of volunteers.

The parachute forces' capability was further undermined by inexplicable decisions at SAAF Headquarters regarding transport aircraft. The nine Transall C-160 aircraft were withdrawn from service, effectively halving the strategic airlift capacity of the Air Force. The C-160 had been the SAAF's most versatile rough and short landing-strip transport aircraft. The project to upgrade the Dakota C-47 fleet to turbo-prop versions with extended fuselages proved an expensive failure as far as the paratroops were concerned. The upgraded aircraft did not have the capacities that had been

51 Interview with Col Les Rudman in 1993. 


\section{Alexander}

anticipated and were found to be potentially dangerous for static-line parachuting. The Super Frelon helicopters were also scrapped, thereby abolishing to SAAF's only capability for ramp-loading and unloading a rotary-wing aircraft. The paratroopers' vehicles had been designed to drive on and off of the Super Frelon and it was an outstanding helicopter at sea level.

The situation was partially alleviated by the acquisition of Casa tactical transport aircraft with the integration of the Transkei/Bophuthatswana/Venda/Ciskei (TBVC) Defence Forces in 1994, but their numbers did not equal the old Dakotas which were being withdrawn from service. A gift of a few old Hercules C-130 aircraft from the USA helped to increase the airlift capacity of the Air Force, though these too required a lengthy and expensive upgrading programme before they could be effectively employed.

Fortunately, a major step forward regarding air transport took place in the field of helicopters. The replacement of the Puma helicopters with the new, vastly improved Oryx produced a radical increase in the tactical battlefield airlift capacity of the Air Force. This, in turn, gave the paratroopers an impressive heliborne capability. However, the withdrawal of the C-160s meant that these helicopters could no longer be transported over long distances in fixed wing transports without having to dismantle them. It also meant that the SAAF was no longer able to transport a parachute battalion group in one wave over a strategic distance of several thousand kilometres.

The SANDF's intervention in Lesotho illustrated to what extent the paratroopers had been submerged into ground forces and relegated to a purely tactical role in support of those ground forces. Within Lesotho there had been growing political instability during the 1990s and this was impacting negatively on the member states of the South African Development Community (SADC).

In September 1998 the South African government made the decision to intervene militarily in Lesotho in conjunction with Botswana to prevent a suspected coup d'etat in that country. The intended operation would have been a classic opportunity to employ a rapier in the form of a parachute brigade; but alas a sledgehammer in the form of a mechanised brigade was used. Two parachute companies and the pathfinder platoon participated in Operation BOLEAS under operational command of the mechanised 43 Brigade.

The paratroopers were helicoptered into Lesotho to occupy what were thought to be minor, isolated objectives on the periphery of the main area of operations. In the event they encountered some of the heaviest resistance and suffered severe casualties. A total of eight paratroopers were killed and nine wounded. However, they acquitted themselves extraordinarily well, taking all their objectives despite being outnumbered and outgunned. ${ }^{52}$

In their first taste of battle since integration, the paratroopers had shown a remarkable unity and professionalism. They may not have been given the responsibility of conducting the overall operation, but that part of it which they had to execute they did with the flair and panache that traditionally characterise the airborne soldier. With a new unity and esprit de corps the paratroopers returned to Bloemfontein. Though they had acquitted themselves well, neither the government nor the military authorities saw them as having an independent, strategic role. Already the decision had been made to 
reduce the brigade to a regiment.

\section{Air assault: independent tactical raids}

The use of helicopters did enable the paratroopers to carry out a number of tactical raids without being attached to ground forces. Their training, organisation and equipment suited this role admirably and it did give them a degree of initiative and independence. Nevertheless they were invariably under command of a non-paratrooper tactical headquarters when planning and executing such operations.

The first of these occurred in July 1980 during Operation KLIPKOP. SWAPO, intent on showing that SCEPTIC had not crippled their offensive ability, carried out a mortar attack on Ruacana base on the edge of western Ovamboland. In retaliation, the South Africans mounted a helicopter assault on Chitado, a small village inside Angola, some $50 \mathrm{~km}$ east of Ruacana. ${ }^{53}$

Using five Allouette III gunships for fire support and five Pumas to transport the paratrooper company in two waves, the force flew in low above the Cunene River, turned north, and the paratroopers disembarked behind some trees just 100 meters from the town. Used as a SWAPO staging base for incursions into the Kaokoveld, it also housed a barracks of MPLA troops and a few frontier guards.

The paratroopers carried out a direct and immediate frontal assault, which encountered surprised resistance. One paratrooper was wounded as they rushed the first buildings. It was their only casualty. Thereafter house-to-house fighting was followed by a sweep of the surrounding bush. By the time the second wave arrived the town had been taken. A total of 27 SWAPO, MPLA and frontier guards were killed, several others captured, and the barracks, SWAPO base and MPLA headquarters were blown up. Documentation and weapons were also captured. By early afternoon the helicopters had withdrawn the paratroopers.

A different company from 1 Parachute Battalion carried out another successful helicopter assault in October 1980. It was called Operation DORSLAND, and took place even further west. A SWAPO signals base had been identified at Iona in the harsh desert mountains north of the Cunene River. The company of paratroopers was flown by helicopter from Ondangwa to the vast desert plain known as the Marienflüss. There they waited two days in the open before being flown in at first light once special forces had confirmed the target. ${ }^{54}$

One platoon was positioned as stoppers, while two others carried out the attack, supported by helicopter gunships. A fourth platoon remained airborne as a reserve. Though they encountered some resistance, the paratroopers quickly took the base, killing 27 guerrillas and destroying the signals equipment.

On 29 December 1981, a company from 2 Parachute Battalion carried out a helicopter assault

\footnotetext{
53 Die Volksblad, 31 July 1980("SA Magte vergeld Ruacana-aanval").

$54 \quad$ Interview with Lt Col Chris Grovè (retd) on 13 June 1995.
} 
on a SWAPO position at Evale in southern Angola, and in the midst of the battle were counterattacked by a battalion of Angolan MPLA troops. In the battle which followed one paratrooper lost his life, three were badly wounded, an Allouette helicopter was shot down, and about 50 of the SWAPO guerrillas were killed. The operation had to be aborted and a hot extraction by helicopters was carried out. ${ }^{55}$

In one significant and well-publicised helicopter operation in March 1983, a 32 Battalion force was used to attack a SWAPO base in the mountains of south-western Angola. Providing supporting fire and acting as cut-off groups was a company from 1 Parachute Battalion, which was also helicoptered into the mountains for this operation, code-named SUPER. During these early years of the eighties, 1 Parachute Battalion deployed as part of Operation MEEBOS for long periods inside Angola. The only period during which the paratroopers deployed for an extended period under a parachute headquarters, they carried out several heliborne operations during this time. .

There were many smaller helicopter actions, involving only a platoon or a section at a time. These, however, were seldom independent raids, but were usually conducted in conjunction with ground operations. On one such operation in Angola, a Puma helicopter inadvertently overflew a SWAPO anti-aircraft emplacement and was shot down with the loss of the three crewmen and twelve paratroopers.

\section{Airborne insertions: independent tactical operations}

Operation STOOMPOT in June 1979 had set the tone for the insertion by air of a company or more, often for an extended period, enabling indirect approaches to be made on objectives, or harassing tactics to be carried out.

For some of these, such as Operation MOONSHINE, in October 1979, a company of paratroopers would be parachuted in by night some 10 to 15 kilometres from known guerrilla bases, and infiltrate to carry out first light attacks. ${ }^{56}$

The last parachute action to be conducted in Angola was Operation PINEAPPLE, in which two companies from 1 Parachute Battalion participated. It took place in June 1988 and as only one C-160 aircraft was available, it carried out four flights to drop all the paratroopers. From the DZ some 30 $\mathrm{km}$ east of Cuvelai, they then walked $50 \mathrm{~km}$ to lay an ambush on a road. When the expected convoy never arrived, they moved further south towards Cuvelai, ran into an Angolan battalion and attacked it. It withdrew, and the paratroopers were evacuated by vehicle. ${ }^{57}$

Insertions by helicopter, both in Angola and in guerrilla-active areas of Namibia, were common during the 1970s and 1980s. Mostly of platoon or section strength, they were normally carried out to initiate extended patrols of seven to fourteen days. The aim could often be to lay ambushes, dominate the area or flush out guerrilla bands.

\footnotetext{
$55 \quad$ Interview with Cmdt "Jet" van Zyl in 1990.

56 Operational Diary of E-Company, 1 Parachute Battalion for 1979.

57 Interview with Lt Col Chris Grovè (retd) on 13 June 1995.
} 
But even before the withdrawal of the SADF from Namibia, the emphasis had begun to shift to operations inside South Africa. Airborne insertions were almost a natural innovation by the paratroopers in these new circumstances.

Since 1984, when political repression in South Africa had resulted in growing unrest in the black ghetto townships, the Army had been deployed to back up the police. It was unglamorous and unpopular work, and the soldiers were not enthusiastic about it. The paratroopers, too, were employed in this role, much to their chagrin. Urban patrols, riot control, cordons and searches and vehicle checkpoints all became a part of life for the paratrooper. With the ending of the war in Angola and Namibia, there was a radical increase in deployments in South Africa.

During December 1990 and January 1991, 2 Parachute Battalion was deployed in the Durban area of Natal. On several occasions the battalion inserted companies into squatter areas by parachuting them onto open fields nearby. This was done largely to create an effect of strength. After the jumps, the companies would carry out patrols and searches, as well as set up quick vehicle check points on approach roads. These operations often yielded illegal weapons, and resulted in the arrest of suspects. ${ }^{58}$

Over the period May to June 1991, 3 Parachute Battalion was deployed in the gigantic urban township of Soweto, just outside Johannesburg, as part of Operation FAGGOT. Similar parachute operations were executed here, initially using Dakota aircraft to drop a platoon at a time onto open fields within the township. Later, on 11 June, C-130 and C-160 aircraft dropped several companies at a time onto areas between the shacks and surrounding mine dumps. Again, weapons were confiscated and suspects arrested. The parachute drops, however, produced an outcry from the recently unbanned $\mathrm{ANC}$, and were stopped. ${ }^{59}$

Nevertheless, on 18 December 1991 a composite company of students, called up to do operational duty over the Christmas university vacations, was dropped from a C-130 near Groutville in Natal to conduct patrols in the politically unstable area.

During 1993, 1 Parachute Battalion was deployed in the KwaZulu/Natal province of South Africa - an area where violence had become endemic. Rural tribal areas were particularly volatile, and the battalion carried out numerous operational jumps amongst the bush-covered hills of this subtropical land. Companies and platoons were dropped into isolated areas to carry out patrols and searches. It proved cheaper than helicopter deployments and far larger forces could be positioned in one go. In addition, the psychological effect of a parachute drop on the often-uneducated tribes people was significant. ${ }^{60}$

By 1995, the incidence of stock-theft on the border between Lesotho and South Africa's Free State province had grown to alarming proportions. Cattle rustlers from impoverished Lesotho were crossing the Caledon River to raid the successful South African ranchers. The problem reached

\footnotetext{
58 Interview with Cmdt Stef du Plessis in 1991.

59 Interview with Cmdt Kobus Hoon in 1991.

60 Interview with Cmdt Nic van den Bergh in 1993.

Scientia Militaria 31(1) 


\section{Alexander}

proportions beyond the ability of the police to handle, and the Army was deployed along the border to assist them.

The paratroopers, too, were deployed, but by parachute. Companies from 1 Parachute Battalion were dropped at different points along the picturesque border to commence patrols. Their spectacular arrival, in full view of the Basuto huts perched on the hilltops on the other side of the river, resulted in an immediate drop in the incidence of stock-theft.

Utilising the technique of airborne insertions, the paratroopers had shown the extreme versatility of vertical deployment in many very different circumstances.

\section{Operation MERLYN: rapid reaction over long distances}

The implementation of UN Security Council Resolution 435 in Namibia led to an unforeseen airborne operation being carried out as one of the final actions of the so-called "Border War". It was an airlanded operation by a parachute battalion group.

As part of the UN resolution, South Africa had disbanded the South West Africa Territory Force. This was a force that had been created in the early eighties to give the appearance of Namibia having its own armed forces, and its members were recruited from amongst the Namibians. However, it was largely officered by South Africans and in fact operated under South African command. One of its battalions, 2 SWA Specialist Unit, was parachute trained in South Africa and often provided a company to act as the resident Fire Force at Ondangwa for a three-month tour of duty. When the SWA Territory Force was disbanded at the end of 1988, the South African officers and NCOs of 2 SWA Specialist Unit were almost all transferred to 14 Parachute Battalion Group at Murrayhill, north of Pretoria.

By 1 April 1989, most South African Defence Force units in Namibia had also been disbanded or withdrawn from the territory, and the few which remained had been confined to barracks under UN supervision. SWAPO elements were supposed to be confined to bases inside Angola, north of the 16th parallel. However, on the night of 31 March 1989, in contravention of Resolution 435 and all other agreements, a heavily armed SWAPO force of more than 1000 , divided into groups of between 100 and 200, crossed the border from Angola into Namibia.

Early on 1 April 1989 these SWAPO groups clashed with lightly armed police patrols. Heavy contacts erupted all along the border, resulting in serious casualties on both sides. The UN Transitional Assistance Group (UNTAG) did not have the resources to counter this breach by SWAPO, and after several days of bloody fighting, the UN authorised the release of six South African battalions to go to the assistance of the badly mauled police.

In South Africa, 44 Parachute Brigade was alerted to prepare 14 Parachute Battalion Group for deployment as of one of these. At the time, most of the battalion group's elements were exercising at the Army Battle School in the Northern Cape. One company was at Ondangwa, ostensibly as the resident Fire Force, but in fact confined to the base. Other elements were in Pretoria and 
Bloemfontein. ${ }^{61}$

After several days of anxious waiting, the brigade commander was given the order to deploy his battalion group to Namibia. At 03 HOO on 7 April 1989 six C-130 and two C-160 aircraft took off from Pretoria. Landing at Sishen in the Northern Cape to collect the bulk of 14 Parachute Battalion Group, they went on to land at Ondangwa. There the artillery battery was detached to assist in the defence of the town of Oshakati. Most of the rest of the battalion, as well as the brigade headquarters, were flown to the isolated base of Ehomba in the Kaokoveld. There an air landed operation was carried out on the tiny dirt airstrip.

Within 14 hours of having been given the order to go, the whole battalion group was deployed on operations. They had flown a total distance of $1600 \mathrm{kms}$ and had carried out three landings in the process. Only two days remained before a cease-fire was implemented. During that time the paratroopers, together with another under-strength infantry battalion that had been mobilised and whom they had reinforced, conducted Fire Force operations, search and destroy patrols and "pseudo" operations in the rugged Zebra Mountains. Twenty guerrillas were killed and a further 20 captured.

After the cease-fire the paratroopers remained in Namibia for several weeks, manning UN supervised assembly points at which the SWAPO guerrillas were meant to report. Predictably, none reported.

Eventually the brigade headquarters and 14 Parachute Battalion Group were withdrawn, leaving only the company at Ondangwa, ostensibly a Fire Force, but in effect confined to base and unable to operate at all. Operation MERLYN had been an outstanding example of the rapid projection of a balanced force by air in response to a crisis situation. Sadly, senior military men in the SADF attached little significance to the potential of this capability at the time. This capability was thus one of the first casualties of the rationalisation process that began in the early 1990s.

The last South African combat element to withdraw from Namibia was the Fire Force company at Ondangwa, a CF company from 4 Parachute Battalion. The paratroopers had been the first Army combat elements into Namibia in August 1966, and were the last out on 4 June 1989. In November 1989 Namibia gained its independence under an elected SWAPO government.

\section{Integration of former adversaries}

In April 1994 the new South African National Defence Force (SANDF) came into being. It was to integrate the former SADF, the "homeland" defence forces of the former Transkei, Bophuthatswana, Venda and Ciskei, as well as the armed wings of the ANC (Umkhonto weSizwe or MK) and the PAC (the Azanian People's Liberation Army or APLA). As the SADF was far larger than all the others combined and as it had the best organisational and administrative infrastructure, it was used as the basis for the new SANDF.

With the exception of the Venda Defence Force, the other TBVC forces all had some form of

61 Interview with Cmdt Nic van den Bergh in 1989. 


\section{Alexander}

airborne capability, and the more significant of these were integrated into 44 Parachute Brigade. The Transkei Defence Force (TDF) had a parachute school at Umtata, built by South Africa, and a special forces unit at Port St Johns, trained by former Rhodesians. Many of the soldiers in the other TDF battalions were also parachute-trained. But out of a total of some 400, only 171 former TDF paratroopers integrated into 44 Parachute Brigade in June $1995 .{ }^{62}$

The Ciskei Defence Force (CDF) had a parachute school and both a very understrength parachute battalion and a special forces unit. Training had been done by Israelis and South Africans, and about 60 of their 150 parachute-qualified CDF soldiers also integrated into 44 Parachute Brigade. Both the TDF and CDF parachute forces were formed for internal operations against dissidents and possible action against external threat from South Africa or from one another. Although both dropped paratroops at times to intimidate their own citizens and deployed elements by helicopter against one another, no significant airborne operations were undertaken by either the TDF or the CDF.

The Bophuthatswana Defence Force disposed of a very efficient parachute school and an understrength parachute battalion. Fully trained by the South Africans, the Bop Parachute Battalion had exercised with elements of 44 Parachute Brigade. It had been formed as a reaction force in case of internal or external threats, but had never carried out actual airborne operations. Some 92 of their 170 paratroopers integrated in June 1995.

The ANC's MK never formed parachute units. However a number of MK cadres qualified as paratroopers in Angola and the Soviet Union and it is possible that more were trained in other countries. The purpose of their training appears to have been merely to enhance their overall military expertise. Some of those trained in Angola participated in parachute operations with small teams of Angolan special forces against UNITA, but the guerrilla nature of the Armed Struggle precluded any consideration of conventional airborne operations. Initially, $15 \mathrm{MK}$ members were trained in Angola in 1978/1979 at the old Portuguese Commando centre at Cashito, about 60km north of Luanda. Later about 30 others were trained, some of who were sent to the Soviet Union and East Germany for advanced training. ${ }^{63}$

At one stage MK considered the feasibility of entering South African air space by means of a light civilian aircraft from Mozambique or Swaziland by night. On board the aircraft would be trained guerrillas who would then parachute with their weapons and equipment into the rural areas of the eastern highveld. This form of infiltration would have overcome the difficulty of crossing the border into South Africa. However, MK operative Montso "Obadi" Mokgabudi, who died during an SADF attack on Matola in January 1981 had initiated the idea, and the idea died with him. He had worked for MK's Special Operations section under Joe Slovo and had commanded the attack on the Sasol Refinery on 1 June $1980 .^{64}$ Sadly, no parachute trained MK freedom fighter applied for integration into 44 Parachute Brigade.

Interview with the late Col Piet Nel on 29 June 1995.

Interview with Lt Col David Watson on 12 June 1995. Under the nom de guerre "Stewart" he underwent parachute training as one of the first $15 \mathrm{MK}$ members to be selected for this course.

Howard Barrell, MK - the ANC's Armed Struggle (London, Penguin, 1990), pp 42 and 46-47. 
Neither were there any such integrees from the PAC's APLA. This is not surprising, as only one person in APLA is known to have undergone parachute training. This was Yusuf Thika, who was trained in Zimbabwe as part of an investigation into all means of possible infiltration by both air and sea. He subsequently opted against integration into the SANDF. ${ }^{65}$

Some MK and APLA volunteers who had never received parachute training before were integrated into 44 Parachute Brigade after being trained by the brigade. So too were large numbers of new recruits who had never belonged to any former force. But with the termination of conscription in 1993, the numbers of whites volunteering for parachute training rapidly dwindled. By 1995 virtually all the soldiers in 1 Parachute Battalion Group were black.

A decision was made to close down the smaller parachute bases and schools in former Transkei, Ciskei and Bophuthatswana and to concentrate all those men who wished to continue serving as paratroopers in Bloemfontein. Though this meant that 1 Parachute Battalion Group received a significant injection of full-time soldiers, it also meant that differing standards and methods of training had to be integrated, and inevitably a new culture amongst South Africa's paratroopers became apparent. Predictably, the process of integrating a force of such disparate backgrounds was fraught with challenges, placing high demands on the commanders.

Unfortunately, in the process the parachute battalion group concept died. 1 Parachute Battalion Group became once again merely 1 Parachute Battalion and the artillery, engineers, anti-aircraft and logistic elements were sent back to their respective corps.

Subsequent operational deployments were a lot less exciting than had been the case in the past. With other infantry battalions, 1 Parachute Battalion provided companies in various parts of the country to assist the South African Police Service in the combating of crime which had reached epidemic proportions in some areas. They also deployed along the country's borders to prevent the growing influx of illegal immigrants from other countries as well as stock-theft and the smuggling of contraband. Airborne operations as a concept again became no more than a vaguely defined theory.

\section{Categories of airborne operations}

From this brief examination of South African airborne operations, both in concept and in practice, over the second half of the twentieth century, certain categories emerge. In measuring the capability of any existing parachute force, or in identifying its purpose in the SANDF, it may be useful to test its ability to carry out each of these categories. In summary, they could be defined as the following:

a. The Provision of Strategic Reach by means of Independent Operations. This is without doubt the most important potential role for an airborne force. It is what makes the airborne force unique and what gives it its greatest value. It entails the transportation of a balanced (not just infantry) force over a distance of thousands of

\footnotetext{
65 Interview with Yusuf Thika (alias Bush Alexander) on 26 June 1995. 
kilometres within a matter of hours, able to go into action immediately and logistically sustained for several days in action, all without reliance on adjoining ground forces. Examples of such operations would be raids, interventions, rescues, reinforcements, and deterrent actions and peace enforcement. Landings could be opposed or unopposed.

b. Independent Tactical Insertions. Though carried out as part of a broader tactical plan, such airborne insertions would need to be independently executed by an airborne force, not necessarily balanced (ie, it could be only infantry), but logistically selfsustaining. Examples could be harassment actions, patrolling and indirect approaches for the carrying out of attacks, laying of ambushes and cutting off of fleeing forces. They could also include the occupying of defiles and the establishment of beach, bridge or airheads. Landings would not normally be opposed and would usually take place at night.

c. Tactical Air-Mobility. Conceivably including parachute operations, these would far more likely be helicopter-borne. The concept would be based on the provision of mobility on the battlefield to the force concerned, and this mobility would be by air. It would require highly skilled helicopter pilots, making use of nap-of-the earth flying techniques. Troops would require highly developed embarkation and disembarkation skills and command and control would need to be airborne. Helicopter fire-support would also be essential, thereby negating the need for artillery and heavy anti-tank capabilities within the transported force. Logistic support would generally be along ground lines and action would rarely be independent of ground forces because of this. Operations would be integrated into the overall battle plan of ground forces, though the airborne force commander would be involved in all planning. They could include raids, diversions and flanking attacks with the airborne force always employed by its own commanders.

d. Secondary Tactical Role to Ground Forces. In this role the airborne force effectively loses its identity. It is placed under the command of the ground forces and is frequently split up and allocated in a "penny-packet" fashion to low-level ground force elements. Usually the airborne elements are used as a convenient "arm" by the ground commander, stretching out on the flanks or into the shallow front to facilitate ground operations. Logistic and fire-support for the airborne elements is totally dependent on the ground force. More often than not the role played by the airborne elements could have been better accomplished by ground forces, reflecting the oftentotal absence of knowledge by the ground commander of airborne operations. Airborne commanders rarely have any say in their employment during planning of such operations.

\section{Conclusion}

Combating cattle-rustlers and impersonating policeman is a long way from fighting well-trained, 
heavily armed and aggressive guerrillas. However, times had changed for the South African paratroopers and adaptation was necessary. With the advent of democratisation in South Africa in 1994, former enemies have become comrades in arms. The process of integration between former liberation movements and other forces and the advent of a volunteer army have changed the whole character of the airborne units in the new South African National Defence Force.

The concept of vertical envelopment, however, remains alive and relevant. Whether the new South African National Defence Force in its design and training is going to continue to embrace this unique and flexible form of warfare remains to be seen. Initial indications are that it will not. Severe budget cuts, radical changes in command and control systems, the reduction of 44 Parachute Brigade to a regiment, and the decreased airlift capacity have all contributed towards a loss of the ability to deploy a balanced and potent independent airborne force.

Today the paratroopers of 44 Parachute Regiment have the ability to deploy no more than two or at the most three infantry companies by air, supported by light weapons of limited range, over relatively short distances and for very brief periods. This restricts them to airborne operations such as backing up the Special Forces Brigade, small-scale counter-insurgency operations (such as Fire Force) or providing a large conventional force such as a mechanised brigade with a small airborne arm for ancillary tactical operations. There can be no question of independent airborne operations against a distant, strategic objective. Nor even an independent long-distance interventionist operation to rescue South African nationals or protect South African interests. The airborne logistic requirements alone would make this impossible.

It seems almost ludicrous that South African has opted for maintaining a brigade of highlytrained special forces, intended to operate in very small teams, but maintains only a regiment of paratroopers, intended to operate in a conventional or semi-conventional environment against balanced forces with high mobility and fire-power. In other countries where this practice is followed, the special forces invariably end up taking over the role of the paratroopers and watering down their own capability, whilst the paratroopers become no more than but in fact normal infantry with a somewhat elite but undeserved reputation. Certainly they are no longer unique in their role.

This, however, is in line with the airborne capability of the military in most developing countries and positions the South African parachute forces in the same category as those of other such countries. What it does mean, however, is that South Africa's ability to project a significant force strategically is greatly impaired, and this needs to be taken into account if the country wishes to play a prominent role as a regional power.

It is only an Army force that can hold ground; essential if any military operation is to be carried out at any distance from South Africa. Even if the operation is a rapid rescue of hostages (such as the Israeli raid on Entebbe in 1977 or the Belgian attack on the then Stanleyville, now Kisangani, in the Congo in 1964), the ground has to be held for the duration of the action on the ground.

However, where long strategic distances are involved, the Army force needs to make use of the Air Force or the Navy to transport it to the area of operations. If time is not a limiting factor, and the necessary port facilities are available, the Navy is a good option because it enables large numbers in 


\section{Alexander}

terms of personnel and heavy items in terms of vehicles and equipment to be transported. It also means the force can lie off shore, remaining afloat, for a long period, to wait for when it is needed.

But where action is required at short notice, the Air Force provides a better option. However, should there be no infrastructure such as a port or serviceable airfield available, the force would need to be delivered by parachute. History has proved to us that in Africa a crisis situation frequently demands this option (more than 30 such operations have been carried out in Africa since 1956).

If the parachute force earmarked for such operations is not balanced in its composition and capable of operating independently for at least a few days, and if the Air Force is unable to deliver it over the distances required and in the quantities needed, this option cannot be exercised.

It is this that South Africa has to bear in mind when considering whether proper airborne operations are to be an option to prepare for in the future. 